\title{
Sleep quality and daytime sleepiness in university students: prevalence and association with social determinants
}

\section{Qualidade do sono e sonolência diurna em estudantes universitários: prevalência e associação com determinantes sociais}

\author{
Mayonara Fabíola Silva Araújo' (D) mayonarafabiola@gmail.com \\ Xaíze de Fátima de Medeiros Lopes ${ }^{1}$ (D) xaizemedeiros@hotmail.com \\ Carolina Virginia Macedo de Azevedo² (D) carolina@cb.ufrn.br \\ Diego de Sousa Dantas ${ }^{3}$ (D) diegodantas1@gmail.com \\ Jane Carla de Souza' (1) jane.souza@ufrn.br
}

\begin{abstract}
Introduction: Changes in the Sleep/Wake Cycle (SWC) of university students can have consequences on physical, mental and social health. In addition, some behaviors adopted at this stage may be associated with SWC impairment.

Objective: Therefore, this study aims to identify which factors of social determinants of health (SDH) are associated with poor sleep quality and excessive daytime sleepiness (EDS) in university students.

Method: This is a cross-sectional study that included 298 university students, aged between 18 and 35 years; $73.2 \%$ of the students were females and from the countryside of the state of Rio Grande do Norte, Brazil. Data were collected from the following questionnaires: Health and Sleep, Munich Chronotype Questionnaire, Pittsburgh Sleep Quality Index and Epworth Sleepiness Scale. To assess the association of SDH with poor sleep quality and excessive daytime sleepiness, Poisson Regression with robust variance was performed.

Result: The prevalence of poor sleep quality and excessive daytime sleepiness among the university students was $79.2 \%$ and $51.3 \%$, respectively. Between the intermediate determinants of health, a higher prevalence rate of poor sleep quality was observed in students who reported health problems in the previous month (18.4\%), smoked (23.5\%), drank stimulating beverages close to bedtime (25.8\%) and those who used electronic devices before bedtime during the week (18.4\%) when compared to those who did not have these behaviors. Regarding excessive daytime sleepiness, students who justified bedtime during the week and wake-up time at the weekend because of the academic demand showed, respectively, $27 \%$ and $34 \%$ lower prevalence of EDS than the group that did not have these behaviors.
\end{abstract}

Conclusions: The high prevalence of poor sleep quality and EDS observed among university students was associated to biological factors and most of them, behavioral factors.

Keywords: Sleep; Social Determinants of Health; Students; Somnolence.

\section{RESUMO}

Introdução: As alterações no ciclo sono/vigília (CSV) dos jovens universitários podem acarretar consequências na saúde física, psíquica e social. Além disso, alguns comportamentos adotados nessa fase podem estar associados a comprometimento do CSV.

Objetivo: Portanto, este estudo tem por objetivo identificar quais fatores dos determinantes sociais da saúde (DSS) estão associados à má qualidade do sono è à sonolência diurna excessiva (SDE) de universitários.

Método: Trata-se de um estudo transversal que incluiu 298 universitários, com idade entre 18 e 35 anos, 73,2\% dos estudantes do sexo feminino do interior do Rio Grande do Norte, Brasil. Os dados foram coletados a partir dos seguintes questionários: A Saúde e o Sono, Questionário de Cronotipo de Munique, Índice de Qualidade do Sono de Pittsburgh e Escala de Sonolência de Epworth. Para avaliar a associação dos DSS com a má qualidade de sono e a SDE, realizou-se a regressão de Poisson com variância robusta.

Resultado: A prevalência da má qualidade do sono e de SDE nos universitários foi de $79,2 \%$ e $51,3 \%$, respectivamente. Entre os determinantes intermediários da saúde, observou-se maior razão de prevalência de má qualidade de sono nos estudantes que apresentaram problema de saúde no último mês (18,4\%), fumavam (23,5\%) e faziam uso de bebidas estimulantes próximo ao horário de dormir (25,8\%), e naqueles que usavam eletrônicos antes do horário de dormir durante a semana (18,4\%), quando comparados aos que não adotam esses comportamentos. Com relação à SDE, os estudantes que justificaram o horário de dormir na semana e de acordar no fim de semana por causa da demanda acadêmica apresentaram 27\% e 34\%, respectivamente, de menor prevalência de SDE do que o grupo que não adota esses comportamentos.

Conclusão: As altas prevalências de má qualidade do sono e de SDE observadas nos universitários foram decorrentes de fatores biológicos e, em sua maioria, de fatores comportamentais.

Palavras-chave: Sono; Determinantes Sociais da Saúde; Estudantes; Sonolência.

\footnotetext{
1 Universidade Federal do Rio Grande do Norte, Santa Cruz, Rio Grande do Norte, Brazil.

2 Universidade Federal do Rio Grande do Norte, Natal, Rio Grande do Norte, Brazil.

${ }^{3}$ Universidade Federal de Pernambuco, Recife, Pernambuco, Brazil.
}

Chief Editor: Daniela Chiesa

| Associate Editor: Kristopherson Lustosa Augusto

Received on 06/03/20; Accepted on 04/05/21. | Evaluated by double blind review process. 


\section{INTRODUCTION}

Professional qualification is a growing demand in the labor market of contemporary society, which leads to an increase in the number of young people seeking higher education'. The National Education Plan (PNE, Plano Nacional de Educação) - through Law N. 10,172/2001, had the goal of providing higher education to at least $30 \%$ of individuals at the age group between 18 and 24 years ${ }^{2}$. As a result, there was an expansion and interiorization of Brazilian universities. In the state of Rio Grande do Norte (RN), Brazil, the federal university created 10 new undergraduate courses from 2011 to 2015, among which are 4 courses in Faculdade de Ciências da Saúde do Trairi, located in the countryside of the state ${ }^{3}$.

However, entering higher education is considered a stressful experience, especially in the first years of undergraduate school, when adolescents grow into adulthood ${ }^{4}$. This phase can have consequences for the students' lives, which range from the delimitation of personal identity, professional choices, changes in the friendship and social support networks, living far from one's family, high demands for academic performance and staying in the chosen course'.

The high academic demand imposed on university students leads to a wake extension ${ }^{5}$. In contrast, the start classes in the morning force students to wake up early, causing sleep deprivation during the week and, consequently, an increase in daytime sleepiness ${ }^{5}$.

Sleep is essential to maintain one's health and quality of life ${ }^{6}$, and good academic performance ${ }^{7}$. However, for sleep functions to be effective, it is necessary to maintain a daily quantity and quality of sleep, which varies throughout life and from person to person. The recommended sleep duration for young individuals aged between 18 and 25 years is 7 to 9 hours $^{8}$.

Added to the difficulties associated with academic demands, young individuals' sleep is often affected by habits that are considered unhealthy, such as regular consumption of psychoactive substances, such as tobacco, alcohol and coffee ${ }^{5}$, a sedentary lifestyle ${ }^{6}$ and inappropriate eating habits ${ }^{9}$.

Another common behavior of higher education student is to use media device at night. The use of smartphones after 9:00 pm is related to worse sleep quality, later awakening and a longer period of time to initiate sleep ${ }^{10}$. These devices emit artificial light that acts on the body, causing a reduction in nighttime sleepiness, melatonin secretion suppression, delayed bedtime and increased sleepiness in the morning after their use ${ }^{11}$. Azevedo et al $^{12}$ discuss that the knowledge about sleep hygiene habits can be a facilitator for attaining good quality sleep, wellbeing perception and promoting the health of individuals.

It is worth mentioning that the young university students' health is the result of the interaction between the demands inherent to higher education and the social, economic and personal aspects, which can considerably interfere with one's quality of sleep and this population's level of daytime sleepiness. Moreover, all these aspects are considered population health indicators, which can predict chronic health problems, constituting the Social Determinants of Health (SDH).

Simply put, the World Health Organization $(\mathrm{WHO})^{13}$ defines SDH as social conditions in which people are born, live, grow, work and age, such as housing, sanitation, the work environment, health and education services, individual lifestyles (smoking, alcoholism, physical inactivity, eating habits).

Currently, the WHO adopts the model proposed by Solar et al. ${ }^{14}$, which essentially divides the determinants into structural determinants of health inequalities (inequities) and intermediate determinants. The former encompass factors that generate social stratification, such as income distribution, prejudice based on gender, ethnicity, or impairments, and political and governance structures that increase inequities related to economic power, generating socioeconomic status ${ }^{14}$.

Moreover, the authors list macroeconomic policies as contextual factors of these determinants, such as fiscal and monetary policies; policies in the areas of employment, land and housing ownership; public policies in the areas of education, health, drinking water and sanitation, social security and social protection; culture and social values legitimized by society ${ }^{14}$.

The intermediate determinants are categorized into material circumstances (housing conditions, neighborhood characteristics, working conditions, air quality, access to and availability of food and water), behavioral factors (lifestyle and behaviors), biological (genetic factors), psychosocial (psychosocial stressors, stressful circumstances, lack of social support) and the health system ${ }^{14}$.

Considering that there was a growing increase in the university population due to the process of interiorization of higher education and that there are few studies on how the life context of young people in the countryside of the state interferes with sleep, this study aims to identify which factors of the social determinants of health are associated with poor sleep quality and excessive daytime sleepiness (EDS) in university students from the countryside of the state.

\section{METHODS}

This is an observational, cross-sectional study with a quantitative approach, approved by the Research Ethics Committee of Faculdade de Ciências da Saúde do Trairi (CAAE: 72209517.3.0000.5568). A total of 298 students from health courses of an academic unit of Universidade Federal do Rio Grande do Norte, located in the city of Santa Cruz (35,797 inhabitants/624,356 km²) located $17 \mathrm{~km}$ far from the capital city ${ }^{15}$ participated in the study. 
The participants were recruited in the classroom and through social networks, and the sampling technique was carried out by convenience. Data collection took place between November 2017 and June 2019, excluding the months of school recess and holidays. Students older than 18 years of both genders were included in the study after signing the Free and Informed Consent Form. Seven participants were excluded, as they did not complete the questionnaires, and one whose age was outside the average, being considered an outlier.

Four self-applied questionnaires were used:

1. Saúde e o Sono ${ }^{16}$ (Sleep and Health questionnaire), which is widely used in research in Brazil to assess the health and sleep habits of a population, including 20 questions regarding knowledge about sleep. It also assesses information such as: gender, age, whether the student has children, housing conditions, perception about the sleeping place, economic status, having health problems in the previous month, practicing physical activities, reasons related to the usual hours of sleeping and waking up, and habits performed close to bedtime.

2. The Munich Chronotype Questionnaire ${ }^{17}$, which assesses usual sleep and wake times and the midpoint between sleep onset and offset during study days and on free days. Based on this information, it is possible to obtain the individual's chronotype, which is defined by the midsleep on free days corrected for sleep debt on workdays MSFsc), from 0 to 12 hours. In this study, individuals were classified as morning, intermediate or eveningtype individual, according to the criteria proposed by Roenneberg, Wirz-Justice \& Merrow ${ }^{18}$;

3. Pittsburgh Sleep Quality Index, which evaluates the quality of sleep in the previous month based on 7 components (subjective quality of sleep, sleep latency, duration and usual sleep efficiency, sleep disorders, use of sleep medications and daytime dysfunction), and the score for each question ranges from 0 to 3, totaling a final score from 0 to 21 . Global scores from 0 to 5 indicate good sleep quality and

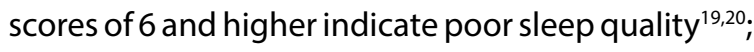

4. Epworth Sleepiness Scale, which evaluates daytime sleepiness through 8 everyday situations in the individual's life regarding the propensity to nap. Each situation is scored from 0 to 3 points, generating a final score ranging from 0 to 24 . Scores up to 10 are considered as indicative of low daytime sleepiness and greater than 10, indicative of excessive daytime sleepiness ${ }^{21,22}$.

The studied variables were distributed into 2 major groups of social determinants of health (SDH), structural and intermediate determinants. The allocation of variables in the groups followed the SDH model proposed by Solar et al. ${ }^{14}$. Therefore, the economic classification, which was categorized into classes A, B, C, D-E by ABEP (Brazilian Association of Research Companies, 2018); work (whether or not one has a job); head of the family's level of schooling (illiterate, basic education and higher education) and the level of knowledge, which was categorized by the median of correct answers $(\leq 13$ correct answers or $\geq 14$ correct answers), were included in the structural determinants of health. Knowledge was assessed based on the 20 statements about sleep in the "Sleep and Health" questionnaire, with the possible answers being: "true", "false" or "I don't know".

The second group comprised the intermediate determinants of health, which was grouped into subgroups of housing conditions, biological and behavioral factors. The housing conditions (living or not with one's family) and sleeping place (good or bad). The latter was assessed according to the participant's perception. The biological factors: gender (male and female); chronotype (morning, intermediate and eveningtype individual); having a health problem in the previous month (yes or no) and age, which was classified according to the age range proposed in the recommendations by the American Sleep Foundation, with young adults being considered those aged 18 to 25 years (individuals aged $\leq 25$ years or $>25$ years).

The behavioral factors included variables related to general life habits and sleep habits performed at bedtime or up to two hours before it, with dichotomous responses (yes or no): practicing physical activity; smoking; drinking stimulating beverages (coffee, black or yerba mate tea, cola soft drinks and guarana); drinking alcoholic beverages; eating inadequately before going to sleep (eating a heavy meal or sleeping hungry); reporting academic demands before bedtime or as a reason to wake up; using electronic devices before bedtime; wake up to do household chores, recreational and religious activities; reporting leisure activities before bedtime.

Data analysis was performed using the SPSS software, version 22. The prevalence of poor sleep quality and excessive daytime sleepiness was calculated. Poisson regression, with a robust variance, provided the Prevalence Ratio (PR) and the respective $95 \%$ confidence intervals $(95 \% \mathrm{Cl})$. The independent variables that were associated with outcomes with $p<0.20$ at the bivariate analysis were included in the multivariate regression models. Statistical significance was set at $p<0.05$. 
It is reinforced that the variable use of electronic devices before bedtime during the week was included in the final regression model of sleep quality, as it has a $p$ value $=0.06$; the literature also showed evidence of the influence of using electronic devices on poor sleep quality ${ }^{10,11}$.

\section{RESULTS}

The prevalence of poor sleep quality and excessive daytime sleepiness (EDS) in university students was $79.2 \%$ and $51.3 \%$, respectively. Most students are females (73.2\%), aged under 25 years (90.6\%), do not live with their families (87.2\%), have moved to live in the municipality where they study $(82,3 \%)$, are from economic classes C (52.3\%) and B (31.9\%), do not work (91.6\%), have a head of the family whose level of schooling is Elementary School (62.1\%), have (52.3\%) a lower level of knowledge about sleep ( $<13$ correct answers) and evaluate their sleeping place as a good one (91.9\%).

Moreover, most of them had chronotype characteristics of an evening-type individual (94.3\%), did not have any health problems in the previous month (56.7\%), reported performing some type of physical activity (52\%) and they did not smoke (98\%) or consumed stimulating beverages $(80.5 \%)$, alcoholic beverages (93.6\%) or inadequate foods (64.1\%).

Regarding the habits related to the sleep/wake cycle, most university students claimed having an academic demand (AD) and using electronic devices (UE) before bedtime during the week $(A D=76.2 \%$; UE $=76.2 \%$ ) and weekend $(A D=69.5 ;$ UE $=86.9 \%)$. Academic demand also appeared as a reason to wake up during the week $(83.9 \%)$ and on the weekend (76.8\%).

Leisure activities (LA) and household chores (HC) before bedtime were reported by the minority during the week ( $L A=$ $26.8 \%$; $\mathrm{HC}=20.8 \%$ ), respectively. However, $75.8 \%$ and $28.5 \%$ of the university students reported doing household chores and leisure activities before bedtime on the weekend, respectively. Furthermore, household chores were not reported by the majority as a reason to wake up during the week (79.5\%) and on the weekend (68.8\%).

Regarding the structural health determinants, no association was observed with poor sleep quality and EDS among the university students. (Table 1)

Tables 2 and 3 show the variables classified as intermediate determinants of health that showed a $p$ value $<0.20$ in the bivariate analysis of the association with poor sleep quality and EDS, which were included in the multivariate regression models. (Tables 2 and 3 ).

Among the variables associated with poor sleep quality, the multivariate regression model showed an $18.4 \%$ higher prevalence (PR $=1.18 ; 95 \% \mathrm{Cl}$ : 1.06-1.32) of poor sleep quality in students who had health problems in the previous month. Moreover, those who smoked ( $\mathrm{PR}=1.23 ; 95 \% \mathrm{Cl}: 1.12-1.36)$, consumed stimulating beverages ( $P R=1.26 ; 95 \% \mathrm{Cl}$ : 1.14-1.38) and used electronic devices ( $P R=1.19 ; 95 \% \mathrm{Cl}$ : 1.00-1.40) before bedtime showed, respectively, a 23.5\%, 26\% and 19\% higher prevalence of poor sleep quality, when compared to young individuals who did not have these behaviors (Table 4).

Table 1. Bivariate analysis of structural health determinants that can influence the poor quality of sleep and excessive daytime sleepiness (EDS) of university students. Santa Cruz / RN. Brazil, 2020.

\begin{tabular}{|c|c|c|c|c|c|c|c|c|c|}
\hline \multirow{4}{*}{ Variables } & \multirow{4}{*}{ Categories } & \multirow{2}{*}{\multicolumn{2}{|c|}{$\begin{array}{c}\text { Poor sleep quality } \\
\mathrm{n}(\%)\end{array}$}} & \multicolumn{2}{|c|}{ Not adjusted } & \multirow{2}{*}{\multicolumn{2}{|c|}{$\begin{array}{l}\text { EDS } \\
\mathrm{n}(\%)\end{array}$}} & \multirow{2}{*}{\multicolumn{2}{|c|}{ Not adjusted }} \\
\hline & & & & & & & & & \\
\hline & & YES & NO & \multirow{2}{*}{ PR (95\%Cl) } & \multirow{2}{*}{$p$ value } & YES & NO & \multirow{2}{*}{ PR (IC 95\%) } & \multirow{2}{*}{$p$ value } \\
\hline & & $236(79.2)$ & $62(20.8)$ & & & $154(51.3)$ & $145(48.7)$ & & \\
\hline \multirow{4}{*}{ Economic class } & Class A & $8(72.7)$ & $3(27.3)$ & \multirow{4}{*}{$\begin{array}{c}0.98(0.81-1.06) \\
1\end{array}$} & \multirow{4}{*}{0.591} & $7(63.6)$ & $4(36.4)$ & \multirow{4}{*}{$\begin{array}{c}0.99(0.85-1.16) \\
1\end{array}$} & \multirow{4}{*}{0.947} \\
\hline & Class B & $77(81.1)$ & $18(18.9)$ & & & $46(48.4)$ & $49(51.6)$ & & \\
\hline & Class C & $125(80.1)$ & 31 (19.9) & & & $82(52.6)$ & $74(47.4)$ & & \\
\hline & Class D-E & $26(72.2)$ & $10(27.8)$ & & & $18(50)$ & $18(50)$ & & \\
\hline \multirow{2}{*}{ Work } & Yes & $20(80)$ & $5(20)$ & \multirow{2}{*}{$\begin{array}{c}1.01(0.82-1.24) \\
1\end{array}$} & \multirow{2}{*}{0.916} & $9(36)$ & $16(64)$ & \multirow{2}{*}{$\begin{array}{c}0.68(0.40-1.16) \\
1\end{array}$} & \multirow{2}{*}{0.361} \\
\hline & No & $216(79.1)$ & $57(20.9)$ & & & $144(52.7)$ & $129(47.3)$ & & \\
\hline \multirow{3}{*}{$\begin{array}{l}\text { Level of schooling } \\
\text { of the head of } \\
\text { household }\end{array}$} & Illiterate & $36(76.6)$ & $11(23.4)$ & \multirow{3}{*}{$\begin{array}{c}1.01(0.92-1.11) \\
1\end{array}$} & \multirow{3}{*}{0.829} & $26(55.3)$ & $21(44.7)$ & \multirow{3}{*}{$\begin{array}{c}1.00(0.84-1.20) \\
1\end{array}$} & \multirow{3}{*}{0.963} \\
\hline & Elementary School & $148(80)$ & $37(20)$ & & & $91(49.2)$ & $94(50.8)$ & & \\
\hline & Higher education & $52(78.8)$ & $14(21.5)$ & & & $36(54.5)$ & $30(45.5)$ & & \\
\hline \multirow{2}{*}{$\begin{array}{l}\text { Knowledge about } \\
\text { sleep }\end{array}$} & $\leq 13$ correct answers & $128(82.1)$ & 28 (17.9) & \multirow{2}{*}{$\begin{array}{c}1.08(0.96-1.21) \\
1\end{array}$} & \multirow{2}{*}{0.207} & $80(51.3)$ & $76(48.7)$ & \multirow{2}{*}{$\begin{array}{c}0.99(0.80-1.24) \\
1\end{array}$} & \multirow{2}{*}{0.983} \\
\hline & $\geq 14$ correct answers & $108(76.1)$ & $34(23.9)$ & & & $73(51.4)$ & $69(48.6)$ & & \\
\hline
\end{tabular}

PR: Prevalence Ratio; Cl: Confidence Interval. 
Table 2. Bivariate analysis of the variables: housing conditions, biological and behavioral factors classified as intermediate determinants of health, which can influence the poor quality of sleep and excessive daytime sleepiness (EDS) among university students. Santa Cruz/RN. Brazil, 2020.

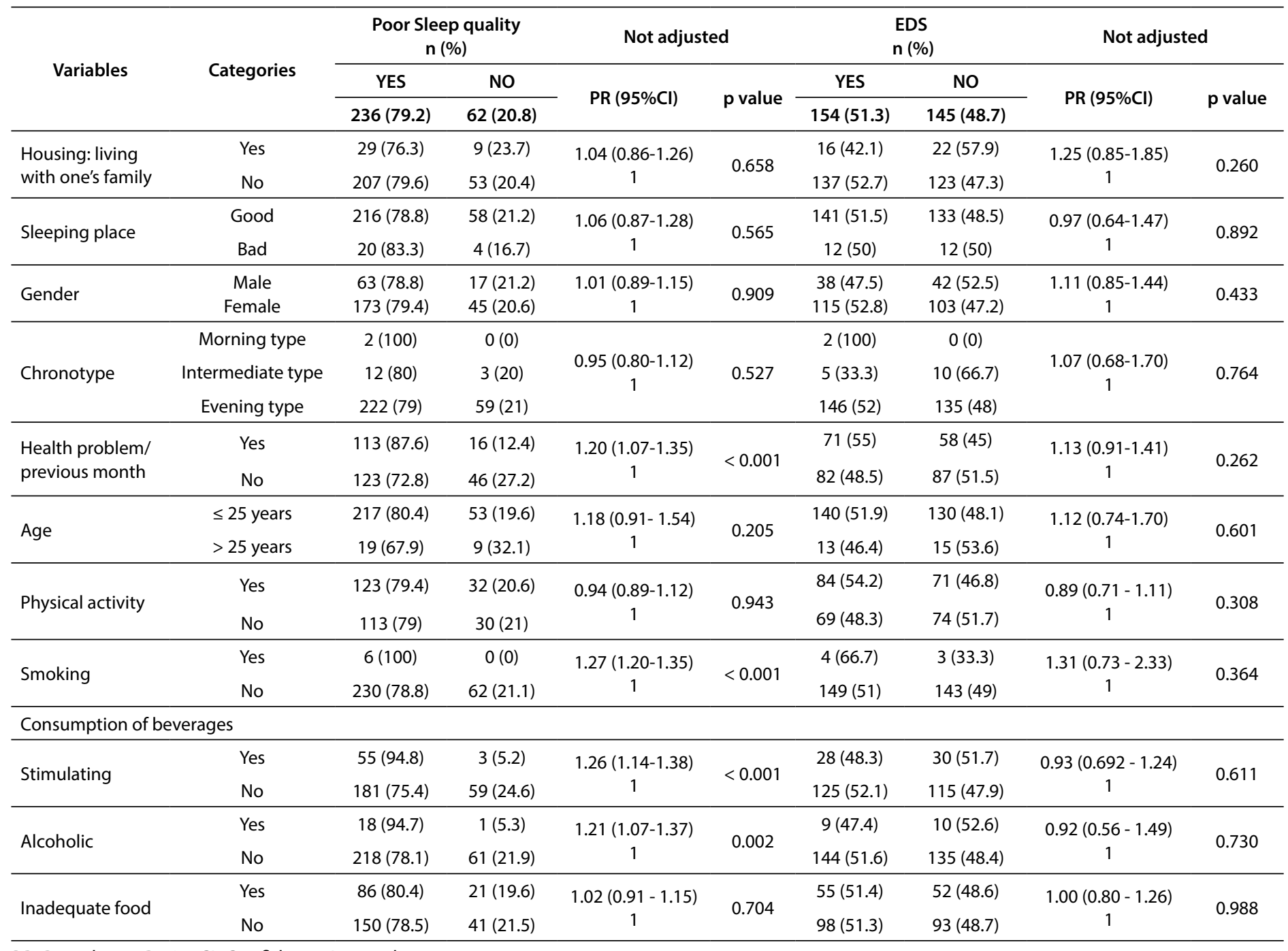

PR: Prevalence Ratio; Cl: Confidence Interval.

In the multivariate regression model, it was observed that those who reported sleeping ( $P R=0.66 ; 95 \% \mathrm{Cl}: 0.48-0.91$ ) because of academic demand on weekdays and wake up (PR $=$ $0.73 ; 95 \% \mathrm{Cl}: 0.54-0.98)$ for the same reason on weekends had a prevalence of $27 \%$ and $34 \%$ lower EDS than the group that did not have this behavior (Table 5).

\section{DISCUSSION}

This study aimed to identify the prevalence and the factors associated with poor sleep quality and excessive daytime sleepiness (EDS) in university students from the countryside of the state of Rio Grande do Norte, Brazil, based on the Solar et al. ${ }^{14}$ model of social determinants of health (SDH).

In the analysis of structural health determinants, no variable was associated with poor sleep quality and excessive daytime sleepiness among the evaluated students. Despite this, this study presents a pioneering contribution to the discussion of the impact of social determinants of health on the sleep of university students, considering that the use of an SDH model that includes several variables minimizes the possible biases of studies that evaluate factors related to health sleep separately. It is also noteworthy that the data were obtained from validated questionnaires widely used in research.

The prevalence of poor sleep quality observed in this study was $79.2 \%$, similar to other studies $(72.2 \%-81.5 \%)$ carried out with university students from city capitals ${ }^{23,24}$. It is worth mentioning that large cities have different cultural and economic characteristics in relation to municipalities located in the countryside of states. In addition to the high academic demands, university students from large cities have a lifestyle that suffers enormous influence from night light pollution, long-distance commuting, greater access to leisure activities, among other factors that negatively impact sleep ${ }^{25}$. 
Table 3. Bivariate analysis of habits related to sleep and wake times during the week and on the weekend, classified as intermediate determinants of health, which can influence the poor quality of sleep and excessive daytime sleepiness (EDS) among university students. Santa Cruz/RN. Brazil, 2020.

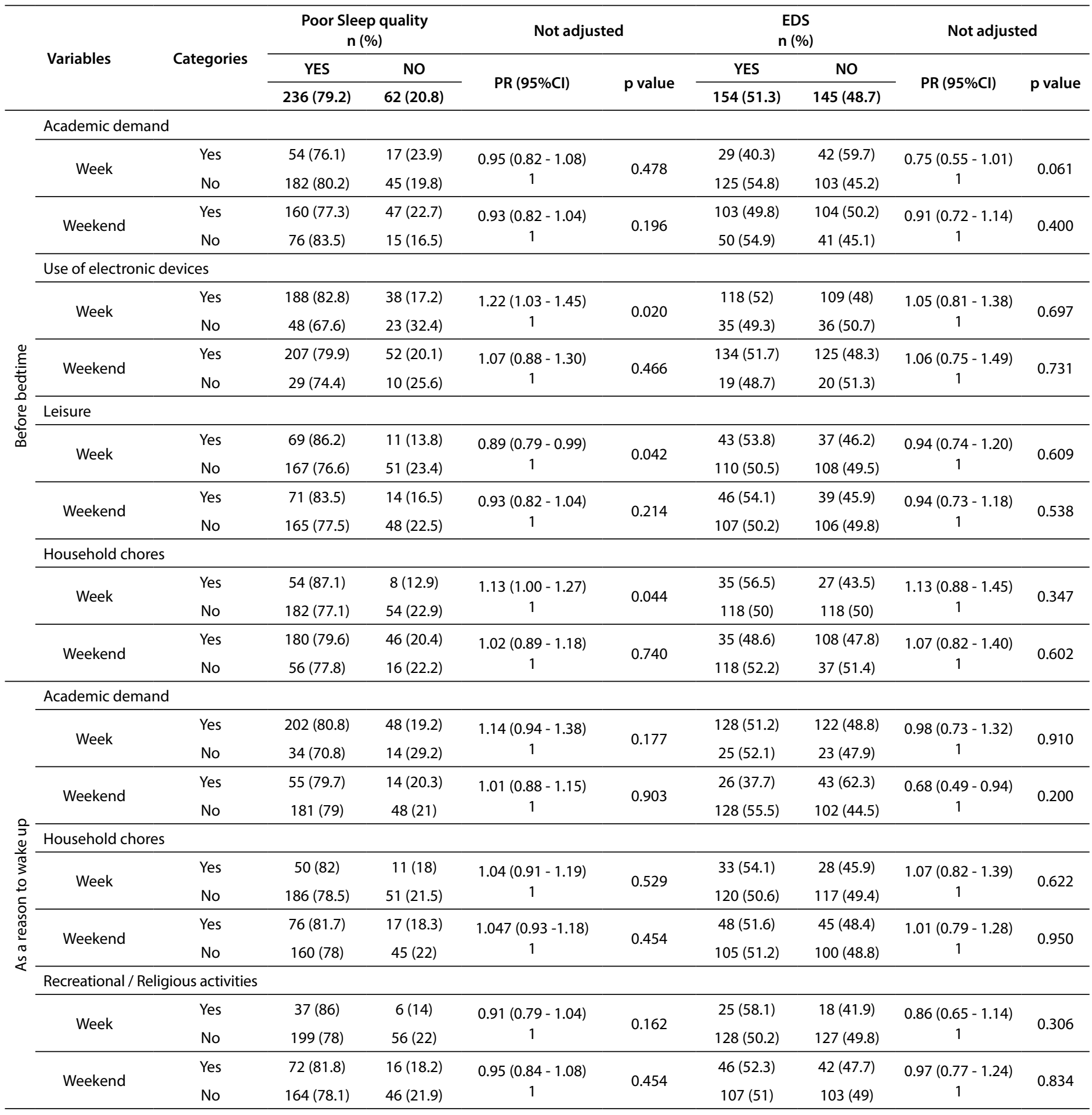

PR: Prevalence Ratio; Cl: Confidence Interval. 
Table 4. Multivariate analysis of the aspects that influence poor sleep quality among university students. Santa Cruz/RN. Brazil, 2020.

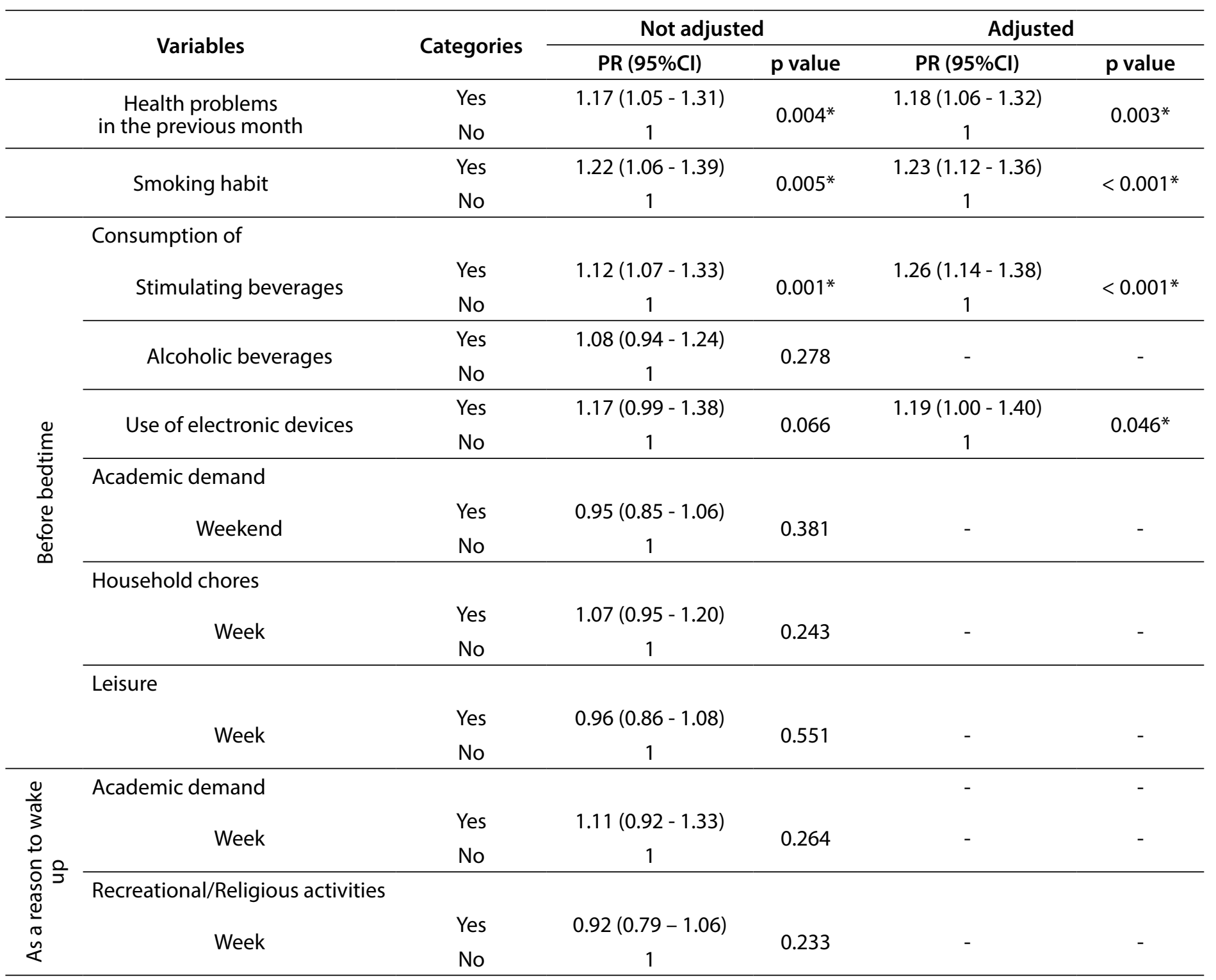

PR: Prevalence ratio; $\mathrm{Cl}$ : Confidence Interval; *Significant value $(\mathrm{p}<0.05)$.

Model parameters: Deviance, $p=0.357$; Omnibus test, $p=0.221$; Sub-dispersion of the data $\left(X^{2}, p=0.211\right)$.

Table 5. Multivariate analysis of the aspects that influence excessive daytime sleepiness among university students. Santa Cruz/ RN. Brazil, 2020.

\begin{tabular}{|c|c|c|c|c|c|}
\hline \multirow{2}{*}{ Variables } & \multirow{2}{*}{ Categories } & \multirow{2}{*}{$\begin{array}{c}\text { Not adjusted } \\
\text { PR }(95 \% \mathrm{Cl}) \\
\end{array}$} & \multicolumn{3}{|c|}{ Adjusted } \\
\hline & & & $p$ value & PR (95\%Cl) & $p$ value \\
\hline \multicolumn{6}{|l|}{ Before bedtime } \\
\hline \multirow{2}{*}{ Week } & Yes & $0.75(0.55-1.01)$ & \multirow{2}{*}{0.061} & $0.66(0.48-0.91)$ & \multirow{2}{*}{$0.035^{*}$} \\
\hline & No & 1 & & 1 & \\
\hline \multicolumn{6}{|l|}{ Academic demand } \\
\hline \multirow{2}{*}{ Weekend } & Yes & $0.68(0.49-0.94)$ & \multirow{2}{*}{0.020} & $0.73(0.54-0.98)$ & \multirow{2}{*}{$0.012^{*}$} \\
\hline & No & 1 & & 1 & \\
\hline
\end{tabular}

PR: Prevalence ratio; Cl: Confidence Interval; *Significant value $(\mathrm{p}<0.05)$.

Model parameters: Deviance- $p=0.677)$; Omnibus test $-p=0.048$; Sub-dispersion of the data $\left(X^{2}, p=0.490\right)$. 
In contrast, this study was carried out with university students from a municipality in which the population maintains countryside municipality habits, as most shops close at lunchtime and operate until the early evening, without hypermarkets or other 24-hour commercial services. Leisure options are reduced to a few restaurants and diners, there are no shopping malls, cinemas, theaters or nightclubs and people usually walk or use the taxi motorbike service, as there are no long distances to get to. Therefore, there is a lack of diversification of economic activities and provision of services in relation to the state capital.

Considering this, the results observed in this study highlight that sleep problems considered frequent in university students in large cities are currently public health problems, which also affect university students from municipalities located in the countryside of the state. This may be due to the expansion of a society that consumes, works and socializes 24 hours a day, 7 days a week (24/7 society), mainly through technology use ${ }^{26}$. Therefore, regardless of the geographical location, the high prevalence of poor sleep quality among university students may be due to the routine of chores, academic demand, socialization and digital stimuli.

In the multivariate regression model, it was possible to observe that some life habits and having health problems were factors associated with poor sleep quality. However, the observed prevalence rates were low when compared to the study by Martinez et al. (2018) ${ }^{27}$. Despite this, the impact of the consumption of stimulating beverages on sleep physiology must be considered, which increases sympathetic activity and sleep interruption ${ }^{27}$, reflecting on poor quality of sleep. The habit of smoking associated with poor sleep quality was also observed in university students from Fortaleza - CE7, which may be associated with disturbances in sleep architecture, resulting in lighter sleep, greater latency in the beginning of sleep and decreased sleep efficiency ${ }^{28}$.

It is noteworthy that the association of poor sleep quality with smoking observed in this study can be assessed as an untrue correlation, considering that only 6 individuals reported these habits. However, we emphasize that the adopted statistical test does not require a sample proportion ratio, as established in tests of comparison of means. Poisson regression with a robust estimator, is considered the most appropriate method to estimate prevalence ratios in cross-sectional studies, whether with common effects ( $>10 \%$ ) or not ${ }^{29}$. Thus, one can infer that the lifestyle of these university students from municipalities in the countryside of the state, who culturally have healthier habits and less access to psychoactive substance exposure may have contributed to the observed result.

Overall, health problems have an impact on sleep quality, which in turn impairs the recovery of the individual's health. It is worth mentioning that sleep is considered fundamental for human health, due to its repair activity, with great influence on the function of the nervous and cardiac systems $\mathrm{s}^{30}$, restoration of energy metabolism, strengthening of the immune system, and feeling of well-being, among others ${ }^{31}$.

Moreover, it was observed that university students who reported "using electronic devices (TV, computer, smartphone) before bedtime" had worse sleep quality. The use of these devices close to bedtime can negatively affect sleep due to the light stimulus, which suppresses melatonin, a sleep-inducing hormone in humans ${ }^{32}$; increasing alertness as a consequence of higher nervous system activity, resulting in difficulty falling asleep 10, which can be even greater if the accessed content has violent, provocative or disturbing characteristics ${ }^{32}$.

Regarding EDS, the observed prevalence was 51.3\%, which can be considered high in comparison to $36.8 \%$ and $32.2 \%$ observed in other studies, which were carried out with a population of the same age group and using the same assessment instrument ${ }^{33,34}$. These studies also found a higher prevalence of EDS in women compared to men. Therefore, considering that our sample consisted mainly of women, this fact may have contributed to the high prevalence observed. However, the literature indicates that the female gender is associated to low complaint of daytime sleepiness; however, this association may be established only in older age groups ${ }^{35}$.

In addition to these factors, EDS may be associated with high academic demands, classes that start very early in the morning, the use of electronic devices before bedtime ${ }^{10,11}$, which demonstrates that sleep quality and daytime sleepiness have a multifactorial influence ${ }^{36-38}$.

Among the intermediate determinants of health, it was observed that the performance of an academic demand to wake up on the weekend and before bedtime during the week was associated with low daytime sleepiness. These behaviors may contribute to the maintenance of a regular sleep schedule, which is related to the observed lower rate of daytime sleepiness ${ }^{34}$. Considering that the literature points out that students tend to wake up earlier during the week, due to the class schedule and spontaneously sleep and wake up later on the weekend ${ }^{33,34}$.

Moreover, these academic demands are carried out under the influence of natural or artificial light, which generates physiological alertness and can cause the individual to have greater resistance or physiological adaptation, generating a bias in the student's perception when filling out the evaluation scale of daytime sleepiness. In addition, there are individual differences regarding biological need for sleep duration ${ }^{39}$. In this sense, even if the students are performing academic 
demand before bedtime and to wake up, which could lead to sleep deprivation and EDS, this may not be happening, because the students may be short sleepers and be fulfilling the need biological sleep.

It is important to highlight that the association between academic demand and less sleepiness could be related to the morning social habits experienced in municipalities located in the countryside, with greater alertness at wake-up time ${ }^{40}$. However, this influence of the morning chronotype was considered in the study and showed no significant association with daytime sleepiness.

Thus, the prevalence of poor sleep quality and excessive daytime sleepiness among the university students assessed herein are due to the individual's health conditions and most of them are behavioral ones. These results are of the utmost importance to contribute to discussions and planning of classes and extracurricular activities (studies, internships, complementary activities), considering a flexible study schedule, to promote better adaptation to the students' sleep schedules.

As limitations of this study, it is emphasized that the analysis of structural health determinants may have been impaired, considering that these determinants encompass complex and broad contextual factors, such as public policies of education, housing, macroeconomic ones and others. In view of this complexity of the structural determinants of health and the fact that the economic classification of ABEP is related to the family's socioeconomic situation and not to the housing conditions to which the student is exposed, our results may have been impaired, since $82.3 \%$ of the participants assessed in this study moved to the municipality where the university campus is located, thus having housing conditions that are different from the family context.

Additionally, it is noteworthy that $52 \%$ of the university students in this study did not reach the minimum score of knowledge about adequate sleeping habits. This demonstrates that the importance of sleep for one's health is possibly scarcely discussed during the training of these professionals. However, knowing about sleep hygiene does not necessarily lead to the practice of adequate habits, since students may be exposed to high academic demands, which are usually carried out at night.

It is expected that this study will be used as a subsidy to foster discussions at the university level that will result in improved sleep quality and decreased EDS, providing better quality of life, health and learning conditions for young university students. Moreover, it is expected that it will allow discussions on the implementation of educational programs on sleep, which may contribute to the development of public policies, particularly in the context of the interiorization of education.

Moreover, the assessed students are health professionals in training and these discussions can help them to become more sensitive professionals, capable of preventing, identifying and intervening in sleep disorders, resulting in positive impacts on the social level and population health.

\section{CONCLUSIONS}

The university students from the countryside of the state of RN showed a high prevalence of poor sleep quality and half of the sample had EDS. Among the social determinants of health, the higher prevalence of poor sleep quality was associated with factors considered intermediate determinants of health, such as having a health problem in the previous month, being a smoker, drinking stimulating beverages and using electronic devices before going to sleep.

Regarding EDS, university students who reported carrying out academic demands before bedtime during the week and as a reason to wake up on the weekend were associated with low daytime sleepiness. Among the structural determinants of health, no association was observed with poor sleep quality and EDS.

It is necessary that future studies expand the assessment of other factors that may interfere with the quality of sleep and EDS in this population, such as the time the classes start, sleep duration and irregular sleep/wake cycle.

\section{AUTHORS' CONTRIBUTION}

Mayonara Fabíola Silva Aráujo and Jane Carla de Souza participated in the study conception and design, data acquisition, data analysis and interpretation, writing, review and final approval of the version to be published. Xaíze de Fátima de Medeiros Lopes participated in the study conception and design, data acquisition, analysis and interpretation of data. Carolina Virginia Macedo de Azevedo participated in the study conception and design, writing and review of the manuscript. Diego de Sousa Dantas participated in the study conception and design and in the review of the manuscript.

\section{CONFLICTS OF INTEREST}

The authors declare no conflicts of interest.

\section{SOURCES OF FUNDING}

The authors declare no sources of funding.

\section{REFERENCES}

1. Oliveira CT, Santos AS, Dias ACG. Expectativas de universitários sobre a universidade: Sugestões para facilitar a adaptação acadêmica. Rev Bras Orientaç Prof. 2016;17(1):43-53.

2. Brasil. Lei no 10.172 , de 9 de janeiro de 2001. Plano Nacional de Educação (PNE). Brasília; 2001 [access in 22 apr 2019]. Available from: http://www. planalto.gov.br/ccivil_03/leis/leis_2001/l10172.htm. 
3. Universidade Federal do Rio Grande do Norte. Plano Diretor do Campus de Santa Cruz. Resolução no 073/2017-CONSAD 2017 [access in 24 apr 2019]. Available from: https://ufrn.br/institucional/documentos.

4. Teixeira MAP, Dias ACG, Wottrich SH, Oliveira AM. Adaptação à universidade em jovens calouros. Psicol Esc e Educ. 2008;12(1):185-202.

5. Lopes HS, Meier DAP, Rodrigues R. Qualidade do sono entre estudantes de enfermagem e fatores associados. Ciências Biológicas e da Saúde. 2018;39(2):129-36 [access in 24 apr 2019]. Available from: http://www.uel. $\mathrm{br} / \mathrm{revistas} / \mathrm{uel} / \mathrm{index}$.php/seminabio/article/view/32236/24760.

6. Andrade RD, Felden ÉPG, Teixeira CS, Pelegrinii A. Sono, percepção de saúde e atividade física em adolescentes universitários. Adolescência \& Saúde. 2017;14(4):150-6.

7. Araújo MFM, Freitas RWJF, Lima ACS, Pereira DCR, Zanetti ML, Damasceno MMC. Health indicators associated with poor sleep quality among university students. Rev Esc Enferm USP. 2014;48(6):1082-9 [access in 11 apr 2019]. Available from: http://www.scielo.br/scielo.php?pid=S008062342014000601085\&script=sci_arttext\&tlng=pt.

8. Hirshkowitz M, Whiton K, Albert SM, Alessi C, Bruni O, DonCarlos L, et al. National sleep foundation's sleep time duration recommendations: methodology and results summary. Sleep Heal. 2015;1(1):40-3. doi: 10.1016/j.sleh.2014.12.010.

9. Perez PMP, Castro IRR, Franco AS, Bandoni DH, Wolkoff DB. Práticas alimentares de estudantes cotistas e não cotistas de uma universidade pública Brasileira. Cienc Saude Colet. 2016;21(2):531-42.

10. Amra B, Shahsavari A, Shayan RM, Mirheli O, Moradi BK, Bazukar M, et al. Associação entre o sono e o uso noturno de celular entre adolescentes. J Pediatr (Rio J). 2017;93(6):560-7. doi: 10.1016/j.jped.2016.12.004

11. Chang AM, Aeschbach D, Duffy JF, Czeisler CA. Evening use of lightemitting eReaders negatively affects sleep, circadian timing, and nextmorning alertness. Proc Natl Acad Sci U S A. 2015;112(4):1232-7.

12. Azevedo CVM, Sousa I, Paul K, Macleish MY, Mondéjar MT, Sarabia JA, et al. Teaching chronobiology and sleep habits in school and university. Mind, Brain, Educ. 2008;2(1):34-47.

13. Organização Mundial da Saúde. Redução das desigualdades no período de uma geração. Igualdade na saúde através da acção sobre os seus determinantes sociais. Relatório final da comissão para os determinantes sociais da saúde. OMS; 2010 [access in 12 may 2019]. Available from: http://www.who.int/eportuguese/publications/pt/.

14. Solar $\mathrm{O}$, Irwin A. A conceptual framework for action on the social determinants of health. Soc Determ Heal Discuss Pap 2 (Policy Pract). Discussion Paper Series on Social Determinants of Health 2010;79 [access in 01 feb 2019]. Available from: http://apps.who.int/iris/ bitstream/10665/44489/1/9789241500852_eng.pdf?ua=1\&ua=1.

15. Instituto Brasileiro de Georgrafia e Estatística. Cidades@. IBGE; 2010 [access in 12 may 2019]. Available from: https://cidades.ibge.gov.br/ brasil/rn/santa-cruz/panorama.

16. Mathias A, Sanchez R, Andrade M. Incentivar hábitos de sono adequados: um desafio para os educadores. In: Pinho S, Sagliett IJ, editores. Núcleos de Ensino da Unesp. São Paulo; 2006. p. 718-31.

17. Levandovski R, Sasso E, Hidalgo MP. Chronotype: a review of the advances, limits and applicability of the main instruments used in the literature to assess human phenotype. Trends Psychiatry Psychother. 2013;35(1):3-11.

18. Roenneberg T, Wirz-Justice A, Merrow M. Life between clocks: daily temporal patterns of human chronotypes. J Biol Rhythms. 2003;18(1):8090. doi: $10.1177 / 0748730402239679$.

19. Buysse DJ, Reynolds CF, Monk TH, Berman SR, Kupfer DJ. The Pittsburgh Sleep Quality Index: a new instrument for psychiatric practice and research. Psychiatry Res. 1989;28:193-213 [access in 23 feb 2019]. Available from: https://www.sciencedirect.com/science/article/ pii/0165178189900474?via\%3Dihub.

20. Bertolazi AN, Fagondes SC, Hoff LS, Dartora EG, Miozzo ICS, Barba MEF, et al. Validation of the Brazilian Portuguese version of the Pittsburgh Sleep Quality Index. Sleep Med. 2011;12(1):70-5. doi: 10.1016/j.sleep.2010.04.020.
21. Bertolazi AN, Fagondes SC, Hoff LS, Pedro VD, Barreto SSM, Johns MW. Validação da Escala de Sonolência de Epworth em português para uso no Brasil. J Bras Pneumol. 2009;35(9):877-83 [access in 23 feb 2019]. Available from: http://www.scielo.br/scielo.php?script=sci_arttext\&pid=S180637132009000900009\&lng=en\&nrm=iso\&tlng=pt.

22. Johns MW. A new method for measuring daytime sleepiness: the Epworth sleepiness scale. Sleep. 1991;14(6):540-5.

23. Segundo LVG, Cavalcanti Neto BF, Paz DDA, Holanda MMA. Aspectos relacionados à qualidade do sono em estudantes de medicina. Rev Bras Neurol Psiquiatr. 2017;21(3):213-23.

24. Carvalho TMCS, Silva II, Siqueira PPSS, Almeida JO, Soares AF, Lima AMJ. Qualidade do sono e sonolência diurna entre estudantes universitários de diferentes áreas. Rev Neurociênc. 2013;21(3):383-7.

25. Pilz LK, Levandovski R, Oliveira MAB, Hidalgo MP, Roenneberg T. Sleep and light exposure across different levels of urbanisation in Brazilian communities. Sci Rep. 2018;8(1):1-11.

26. Bezerra BB. Sociedade de consumo e o universo 24/7. MATRIZes. 2017;11(1):213-6.

27. Martinez G, Escãno HC, Sousa MH, Pinto CAL. Impacto do etanol e consumo de café na qualidade de sono de acadêmicos de medicina. Rev Med (São Paulo). 2018;97(3):267-72 [access in 19 apr 2019]. Available from: https://www.revistas.usp.br/revistadc/article/view/144015/141864.

28. Jaehne A, Loessl B, Bárkai Z, Riemann D, Hornyak M. Effects of nicotine on sleep during consumption, withdrawal and replacement therapy. Sleep Med Rev. 2009;13(5):363-77 [access in 11 apr 2019]. Available from: https://www.sciencedirect.com/science/article/pii/ S1087079208001329?via\%3Dihub.

29. Legler U, Roback P. Chapter 4. Poisson regression. In: Broadening your statistical horizons: generalized linear models and multilevel models. Florida Ed CRC press. 2019. p. 440 - 454 [access in 11 may 2020]. Available from: https://bookdown.org/roback/bookdown-BeyondMLR/ch-poissonreg.html.

30. Jansen J, Lopes A, Jansen U, Capone D, Maeda T, Noronha A, et al. Medicina da noite: da cronobiologia à prática clínica. 2008. p. 340

31. Guimar SS. Impacto dos transtornos do sono sobre o funcionamento diário e a qualidade de vida. Estud Psicol. 2007;24(4):519-28.

32. Owens J, Maxim R, McGuinn M, Nobile C, Msall M, Alario A. Televisionviewing habits and sleep disturbance in school children. Pediatrics. 1999; 104(3) p.01-08.

33. Barbosa SMML, Batista RFL, Rodrigues LDS, Bragança MLBM, Oliveira BR Simões VMF, et al. Prevalência de sonolência diurna excessiva e fatores associados em adolescentes da coorte RPS, em São Luís (MA). Rev Bras Epidemiol. 2020;23:e200071.

34. Carone CMM, Silva BDP, Rodrigues LT, Tavares PDS, Carpena MX, Santos IS Factors associated with sleep disorders in university students. Cad Saude Publica. 2020;36(3):1-16.

35. Silva A, Andersen ML, Mello MT, Bittencourt LRA, Peruzzo D, Tufik $S$. Gender and age differences in polysomnography findings and sleep complaints of patients referred to a sleep laboratory. Brazilian J Med Biol Res. 2008;41(12):1067-5.

36. Bittencourt LRA, Silva RS, Santos RF, Pires MLN, Mello MT. Excessive daytime sleepiness. Encycl Neurol Sci. 2014;27(Suppl I):233-5.

37. Winwood PC, Lushington K. Disentangling the effects of psychological and physical work demands on sleep, recovery and maladaptive chronic stress outcomes within a large sample of Australian nurses. J Adv Nurs. 2006;56(6):679-89 [access in 13 may 2019] . Available from: https://www. ncbi.nlm.nih.gov/pubmed/17118046.

38. Pereira ÉF, Teixeira CS, Louzada FM. Sonolência diurna excessiva em adolescentes:prevalênciaefatoresassociados.RevPaulPediatr.2010;28(1):98103 [access in 23 apr 2021]. Available from: http://pepsic.bvsalud.org/scielo. php?script=sci_arttext\&pid=S1415-88092013000200002.

39. Webb WB. Are short and long sleepers different? Psychol Rep. 1979;44:25964. doi: 10.2466/pr0.1979.44.1.259.

40. Duarte LL. Cronotipos humanos. Cruz das Almas, BA: Editora UFRB; 2018 $108 \mathrm{p}$.

This is an Open Access article distributed under the terms of the Creative Commons Attribution License, which permits unrestricted use, distribution, and reproduction in any medium, provided the original work is properly cited. 